\title{
User experience for landscape teaching mobile device software interface
}

\author{
design \\ Long Yan \\ College of Urban Construction, Wuhan University of Science and Technology, Wuhan, China \\ Lo20009@163.com
}

Key words: Interface Design, UED, Interaction, landscape teaching

\begin{abstract}
Based on the technical characteristics of human-computer interaction, combined with the interface design theory, the viewpoints that divided the interface design elements into the dominant and implicit factors are raised. Meanwhile, the model that design implicit elements dominantly is established. For landscape teaching mobile device interface design, through knowledge transmission and transformation among requirements analysis, development design, and test, user experience oriented interface design process is constructed. And the model that map the relationship between the interface providers and the interface recipients. The research of the user interface design of mobile landscape teaching devices is a new research topic in the field of human-computer interaction. The traditional user interface design methods are inadequate to meet the increasingly complex interactive environment. Under such circumstances, this paper suggests that the user experience should be emphasized during the process of designing the interactive interface. It investigates the effect of the user experience design on the mobile device user interface design idea.
\end{abstract}

\section{Introduction}

With the rapid development of information technology and the Internet, the technical innovation shape is changing. The user-centric, human oriented design attracts more and more attention. And the interface design is much more concerned. It has experienced from meeting users' functional and aesthetic needs to that increasingly concerned about humanization and the users' experience. It has become an inevitable trend.

Since the third wave in human-computer interaction (HCI), research on user experience has gained momentum within the HCI community. The focus has shifted from systematic usability requirements and measures towards guidance on designing for experiences. This comprehensive user-centered approach provides an agenda for information research, design, and education that challenges many accepted beliefs and suggests new directions for work. This article proposed the development and design model of user experience oriented interface from a landscape teaching mobile device mobile landscape teaching software design. The features and process of UED are discussed in depth. And the final product with high user experience been ensured through the participation of users is emphasized.

\section{User Experience Design}

UED's core idea is to design a mobile landscape teaching software product in a line with user habits with the principle of the ergonomics and function study through integrating the factors such as, a comprehensive vision, layout and motion design. Hassenzahl and Tractinsky define the user experience as dynamic, context-dependent, internal states of users, which consist of both 
instrumental and emotional aspects.[1] Excellent UED can reduce development costs, improve customer satisfaction and loyalty, and eventually increase product sales. In the interface design, one of the core issue of the research is how to obtain the user's experience requirements effectively, and to establish the correct user model. So that UED can execute in a natural, efficient and consistent and friendly way.

UED is a subset of the experience design field. The effect of the user experience is the main object of the study. It focuses on the unified whole consists of mobile landscape teaching software and user, rational distribution of the user's habits and the mobile landscape teaching software layout, aiming at enabling users to quickly across complex technical features of product to grasp the operating essentials. In particular, UED is mainly concerned with interactive digital products and systems, and reflects an awareness of the importance of human-computer interface design.[2] Similar comments can also be made on traditional methods in HFE [3], although more types of products are involved in HFE. Law et al.recommend the term UX to be scoped to products, systems, services, and objects that a person interacts with through a user interface.[4] This is also echoing the ISO definition of UX: a person's perceptions and response that result from the use or anticipated use of a product, system, or services [5]. Good user experience design is the key that mobile landscape teaching software not only can cater to the audience's habits, but also as an important measure of improving customer satisfaction, increasing product sales, and saving costs. It is also identified that user co-production formed the core of the service system and its processes.[6] Therefore, most of the mobile landscape teaching software design company views UED as an important part of mobile landscape teaching software design and pay significant attention. The subject knowledge UED involved shown in Figure 1.

\begin{tabular}{|c|c|c|c|c|c|c|c|}
\hline $\begin{array}{c}\text { Brand } \\
\text { management }\end{array}$ & $\begin{array}{l}\text { Information } \\
\text { architecture }\end{array}$ & $\begin{array}{l}\text { Interface } \\
\text { design }\end{array}$ & availability & $\begin{array}{l}\text { Interaction } \\
\text { Desig }\end{array}$ & $\begin{array}{l}\text { Technical } \\
\text { support }\end{array}$ & sociology & psychology \\
\hline $\begin{array}{c}\text { Project } \\
\text { Management }\end{array}$ & $\begin{array}{l}\text { Index } \\
\text { Science }\end{array}$ & $\begin{array}{l}\text { Visual } \\
\text { Design }\end{array}$ & $\begin{array}{l}\text { Structure } \\
\text { Design }\end{array}$ & Ergonomics & $\begin{array}{l}\text { Computer } \\
\text { Graphics }\end{array}$ & $\begin{array}{c}\text { Business } \\
\text { Environment }\end{array}$ & $\begin{array}{l}\text { Consuming } \\
\text { Behavior }\end{array}$ \\
\hline $\begin{array}{l}\text { Commercial } \\
\text { Marketing }\end{array}$ & $\begin{array}{r}\text { Artificial } \\
\text { Intelligence }\end{array}$ & $\begin{array}{l}\text { Icon } \\
\text { Design }\end{array}$ & $\begin{array}{l}\text { Usability } \\
\text { Engineering }\end{array}$ & \begin{tabular}{|c|} 
Human-computer \\
Interaction \\
Technology \\
\end{tabular} & $\begin{array}{l}\text { Image } \\
\text { Processing }\end{array}$ & $\begin{array}{l}\text { Business } \\
\text { Analysis }\end{array}$ & $\begin{array}{l}\text { Experimental } \\
\text { psychology }\end{array}$ \\
\hline Marketing & $\begin{array}{c}\text { Data } \\
\text { Modeling }\end{array}$ & $\begin{array}{l}\text { Color } \\
\text { Design }\end{array}$ & $\begin{array}{l}\text { Usability } \\
\text { Evaluation }\end{array}$ & $\begin{array}{c}\text { User-centered } \\
\text { Design }\end{array}$ & $\begin{array}{l}\text { Communication } \\
\text { Technology }\end{array}$ & Phenomenology & $\begin{array}{l}\text { Cognitive } \\
\text { Psychology }\end{array}$ \\
\hline $\begin{array}{l}\text { Product } \\
\text { Strategy }\end{array}$ & $\begin{array}{l}\text { Library } \\
\text { Science }\end{array}$ & $\begin{array}{l}\text { Industrial } \\
\text { Design }\end{array}$ & $\begin{array}{l}\text { Software } \\
\text { Testing }\end{array}$ & \begin{tabular}{|c} 
Human-computer \\
Interaction \\
Design
\end{tabular} & $\begin{array}{l}\text { Sof tware } \\
\text { Engineering }\end{array}$ & Anthropology & $\begin{array}{l}\text { Cognitive } \\
\text { Science }\end{array}$ \\
\hline
\end{tabular}

Figure 1 The subject knowledge UED involved

In the early stages, designers generally considered that it is art designer who masters the interface design which led to the disconnection of mobile landscape teaching software's usability and aesthetics. So the feed back from the users is not ideal. However, in recent years, mobile landscape teaching software design companies are increasingly concerned about the design of the interface, make efforts to solicit the views of users, design the mobile landscape teaching software based on UED and improve customers' satisfaction. For example, Wang Dan li. proposed a user-centric pen-styled interface design methods based on the scene tree, and described it with an example of the conference management system. Blythe studied the user experience by stimulating scenario with the examples of Apple's iPod, an online shopping system Net Neighbor and the elderly wrist alarm Cam badge. With the example of Singapore and Philippines, Seva studied how the mobile phone features affect user experience. He shows that Singapore pay more attention to the function, while Philippines pay more attention to aesthetic characteristics. The result shows that simulating scenarios is an effective method of user experience research and the impact of social and cultural to the new technology. With the example of blue-collar workers in Mumbai, Lalji utilized 
the user-centered and incremental design methods to design the mobile phone interface prototype for the illiterate through the user's situation and experience.

In accordance with the standard ISO13407, user-centered design approach aims to integrate the views and needs of the user to the service and the product development process. It is supplementary rather than substitution to the development strategy. Keil suggested that the success of the project whether the user directly involved in; Wang Danli utilized the Scene Description to reflect the user-centered design idea. With the design of the system from the user's point of view, he put forward a kind of user-centered scene design approach. He described his theory with an example of the ATM machine interface designing. Google's UED includes two directions, namely research and design, and proposed the quick assessment and testing techniques of the availability, rapid prototyping as well as A / B testing and other methods, etc. based on the Internet characteristics; Alibaba and its companies have also set up UED departments, aimed at co laboring departments to optimize their service by researching users; Baidu's UED department emphasized that support professional and systematic information of user experience to the other sectors the in the work of improving and optimizing the network interface design; Tencent set up the user research and experience design center. Its function is to research user and experience oriented design. With the steadily raising of the user position in application development, participatory design has become a hotspot of user-centric development.

UED is an emerging cross-disciplinary field. In academic field it has not formed a complete set of system, improved and standard the methods to guide the design practice yet. In the industry field, due to the different situations of each company as well as trade secrets and other reasons, Chinese enterprises are still in the exploratory stage at present. It is difficult for them to imitate and learn from foreign practices. They are lack of support for some theory and methods in practice. In this paper, the interface design methods and processes for the user experience is proposed, it can provide some guidance references for landscape teaching mobile device mobile landscape teaching software development practices and design education.

In Figure 2, there is an experience interface between the service provider and user. The service provider, conveys the service content to the user through a specific service interface by means of network and landscape teaching mobile devices. There are many contact points of experience on the service interface. Users perceive the service through experience contact points, make the evaluation and feedback according to their own understanding and experience. Service provider makes improvements and upgrading after receiving feedback from users. Notably users' cognitive and affective aspects are accommodated in the design and delivery process of products and systems. While the cognitive aspect focuses on users' information processing and decision-making processes [7], the affective aspect focuses on users' affective responses and inspirations.

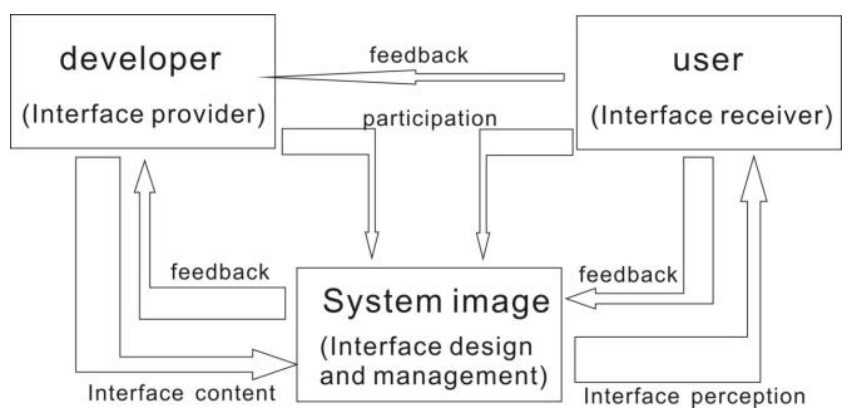

Figure 2 an experience interface between the service provider and user 


\section{The actual development phase of mobile landscape teaching software}

The actual development and design of the mobile landscape teaching software consists of two aspects, namely the interface design and the function design. Based on the previous model design, all aspects should be displayed in visual forms. And the mobile landscape teaching software should be written on the computer with a specific mobile landscape teaching software program. During the meantime, the style of the interface should be taken into account. The interface icons, background designs and colors selections should be considered. The aesthetic and practicability of the interface effect should be guarantied at the basis of meeting the basic function.

\section{Conclusion}

Product testing session is to test the utilization of features and interface of the written mobile landscape teaching software, to detect whether it meets the specific requirements of the users, whether it follows the basic rules of running. The security and functionality of the mobile landscape teaching software should be assessed integrity. Unstable factors and inharmoniousness of the interface should be detected. The causes should be further detected and the product should be corrected until meet the users' needs. UED advocates an iterative prototypes are developed and tested.Publishing and maintenance are the final stage of mobile landscape teaching software design. Through a series of tests, the product can be published. During the mean while, the after-sales service should be fulfilled. The designer should collect the users' feedback information and gain experience for upgrading the next mobile landscape teaching software.

\section{Acknowledgments}

This paper is funded by Project of Hubei Humanities and social science bureau.No:16Q044.

\section{References}

[1] Hassenzahl M, Tractinsky N (2006) User experience-a research agenda. Behav Inf Technol 25(2):91-97

[2] Carroll JM (2000) Making computer interactions. scenario-based design of human-Press, Cambridge, MA

[3] Talbot J (2005) New interactions: factors' in design. Ergon Aust the role of affective human 1921-25

[4] Law ELC, Roto V, Hassenzahl M, Venneeren APOS, Kort J (2009) Understanding, scoping and defining user experience: a survey approach. In: 27th international conference on human factors in computing systems, Boston, MA, pp 719-728

[5] ISO-9241-210 (2008) Ergonomics of human system interaction-Part 210: human-centered design for interactive system. International Organizaiton for Standardization (ISO)

[6] Design-inclusive UX research: design as a part of doing user experience research. Vermeeren, Arnold P.O.S. Behaviour \& Information Technology. Jan2016, Vol. 35 Issue 1, p21-37. 17p. 2

[7] Clark RE, Estes F (1996) Cognitive task analysis. Int J Educ Res 25(5):403-17 